\title{
Determination of dependence between the content of protein in grain of winter wheat and parameter of fertility of soil
}

\author{
Lisovyi M. ${ }^{1}$, Maliarets L. ${ }^{2}$ \\ ${ }^{1}$ NSC «A.N. Sokolovskyi Institute of soil science and agrochemistry», Chaikovska Str., 4, Kharkiv, 61024, \\ Ukraine, ${ }^{2}$ S. Kuznets Kharkiv national economic university, Nauky avenue, 9a, Kharkiv, 61166, Ukraine;

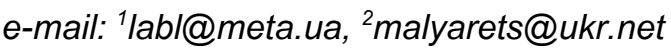

The purpose. To elaborate methodical approach to determination of influence of parameters of soil fertility on the content of protein in grain of winter wheat on the basis of methods of mathematical processing experimental information of field experiments. Methods. Complex of mathematical tools of prospecting analysis, correlation coefficients at studied parameters, regression dependences of content of protein of winter wheat on parameters of fertility of soils, prognostic models of content of protein in grain using equations of growth curves, integrated parameter of the level of soil fertility and its influence upon the content of protein in grain of winter wheat. Results. On the basis of analytical calculations it is determined that change of content of protein in grain of winter wheat depends on change of content of nitrogen of nitrates, content of mobile forms of phosphorus and potassium in soil. In grain of wheat the forecast of content of protein is calculated for 3 nearest seasons. The level of joint influence of three parameters of soil on the content of protein in grain of winter wheat is specified. Methodical approach to mathematical processing the experimental information of field experiments on an instance of determination of dependences of influence of parameters of soil fertility on the content of protein in grain of winter wheat in conditions of steppe zone is developed. Conclusions. Levels are determined of dependence of content of protein in grain of winter wheat from parameters of soil fertility: high - from change of content of nitrogen of nitrates, average — from change of content of mobile potassium,

low - from change of content of mobile phosphorus in soil. Forecast of change of protein in grain for the nearest season has a positive trend.

Key words: field experiments, parameters of soil, winter wheat, protein, mathematical methods, correlation coefficients, prognostic models.

https://doi.org/10.31073/agrovisnyk201902-02

One of the problems of the agrarian sector is the increase in the volume of production of agricultural products of high quality. Winter wheat ranks first among the food crops in Ukraine and other countries of the world. It is known that the quality of wheat grain of winter depends on many factors, namely: weather and climatic conditions, crop rotation, predecessors, fertilizer systems, soil fertility, farming system. Winter wheat forms the crop mainly due to soil fertility and, first of all, due to the availability of its mobile nutrients. It is known that from the nutrients the most important are the mobile compounds of nitrogen, phosphorus and potassium. Therefore, in order to develop measures to increase the quality yield, it is important to establish the influence of soil indicators on the protein content of winter wheat grains.

Analysis of recent research and publications. Questions of the impact of various natural and anthropogenic factors on the protein content of winter wheat were studied by scientists over the years [1 6]. Particular attention was paid to the study of the influence of organic and mineral fertilizers on the quality of wheat grain. Due to the fact that plants form the harvest and grain quality mainly due to natural fertility, there is a certain dependence between soil characteristics and grain quality indices. Therefore, it is important to establish the degree of influence of soil indicators on the quality of winter wheat grain and their interconnection. This problem is not new, but research on its solution to date was not consistent [7 10]. Given the increasing relevance of the problem of obtaining high quality grain, scientists and practitioners continue to research in this direction. It should be noted that the substantiation of the ways of 
solving this problem is possible also due to the use of accumulated experimental information of field experiments and their processing by methods of mathematical statistics [11 - 12].

The purpose of research. To develop a methodical approach to determining the influence of soil fertility indices on the content of winter wheat protein on the basis of mathematical processing of experimental information of field experiments.

Research methodology. The results of field short-term experiments of the agrochemical service on black earths of ordinary low-humus heavy-bulk northern Right-bank and Left-Bank Dnipro Steppe fields were used for research purposes [13]. In this case, the effect of mobile compounds of nitrogen, phosphorus and potassium on the protein content of wheat grain of winter was investigated. Experimental data on the content of moving nutrients in the soil and the content of protein in wheat grains of winter is indicated by: - the content of nitrate nitrate using the Grandval-Lyag method $(N) ; x_{2}$ - the content of mobile phosphorus $\left(\mathrm{P}_{2} \mathrm{O}_{5}\right)$ for Chirikov; $x_{3}$ - content of exchangeable potassium $\left(K_{2} \mathrm{O}\right)$ by the Maslova method; $y$ - protein content in wheat grains of winter (Table 1).

Table 1 - Experimental data on the content of mobile nutrients in chernozem common and the content of protein in wheat grains of

\begin{tabular}{|c|c|c|c|c|}
\hline \multirow{2}{*}{$\begin{array}{l}\text { Field } \\
\text { experim } \\
\text { ent } \\
\text { number }\end{array}$} & \multicolumn{3}{|c|}{ Content of nutrients in soil, $\mathrm{mg} / \mathrm{kg}$} & \multirow{2}{*}{$\begin{array}{l}\text { Protein content } \\
\text { in grain, } \% \\
(y)\end{array}$} \\
\hline & $x_{1}$ & $x_{2}$ & $x_{3}$ & \\
\hline 1 & 2 & 3 & 4 & 5 \\
\hline 1 & 10,0 & 102 & 118 & 8,2 \\
\hline 2 & 11,0 & 90 & 211 & 11,0 \\
\hline 3 & 11,5 & 110 & 233 & 13,0 \\
\hline 4 & 10,5 & 37 & 119 & 12,5 \\
\hline 5 & 14,5 & 97 & 278 & 11,9 \\
\hline 6 & 19,0 & 58 & 340 & 12,9 \\
\hline 7 & 10,5 & 146 & 244 & 12,8 \\
\hline 8 & 29,0 & 126 & 325 & 13,2 \\
\hline 9 & 21,0 & 127 & 285 & 10,7 \\
\hline 10 & 17,0 & 93 & 233 & 12,2 \\
\hline 11 & 14,0 & 92 & 180 & 10,3 \\
\hline 12 & 12,0 & 120 & 205 & 11,6 \\
\hline 13 & 42,0 & 91 & 290 & 13,7 \\
\hline 14 & 18,5 & 85 & 200 & 15,8 \\
\hline 15 & 16,5 & 99 & 220 & 15,1 \\
\hline 16 & 28,0 & 100 & 243 & 16,1 \\
\hline 17 & 21,5 & 117 & 260 & 15,3 \\
\hline 18 & 10,5 & 95 & 210 & 17,8 \\
\hline 19 & 9,5 & 116 & 190 & 14,8 \\
\hline 20 & 14,0 & 91 & 400 & 12,8 \\
\hline 21 & 21,5 & 78 & 254 & 13,2 \\
\hline 22 & 22,5 & 170 & 436 & 11,6 \\
\hline 23 & 10,5 & 94 & 270 & 13,9 \\
\hline 24 & 22,0 & 140 & 200 & 13,0 \\
\hline 25 & 10,0 & 115 & 208 & 12,0 \\
\hline
\end{tabular}




\begin{tabular}{|c|c|c|c|c|}
\hline 26 & 7,0 & 115 & 150 & 14,5 \\
\hline 27 & 11,5 & 85 & 188 & 13,0 \\
\hline 28 & 13,5 & 108 & 288 & 14,0 \\
\hline 29 & 12,5 & 80 & 180 & 13,9 \\
\hline 30 & 8,5 & 114 & 280 & 13,0 \\
\hline 31 & 11,0 & 116 & 245 & 11,5 \\
\hline 32 & 9,5 & 95 & 170 & 9,6 \\
\hline 33 & 4,5 & 80 & 245 & 9,9 \\
\hline 34 & 8,0 & 106 & 230 & 10,7 \\
\hline 35 & 12,5 & 95 & 345 & 13,9 \\
\hline
\end{tabular}

The experimental data are computed using Statgraphics Centurion statistical package.

Research results. The initial stage of the processing of experimental data is an exploratory analysis, which involves a detailed study of the content of mobile nutrients in the soil and the content of protein in wheat grains of winter, based on the study of the laws of the distribution of values of these indicators with the help of descriptive statistics, which include: state indicators that describe the position of the values of the value of the sign on the numerical axis (selective mean, selective median, mod, maximum and minimum value, percentiles, in particular, quartiles); scatter indicators that describe the degree of spread of value values relative to their center and characterize the degree of their variability (variance of the set of values, standard deviation, population velocity, interquartile scale); indicators of the distribution of the values of the value of the sign (coefficients of asymmetry and excess, normalized asymmetry coefficient, normalized coefficient of excess); graphical means describing the law of distribution of values of the value of the sign (histograms, cumulate, block diagrams, frequency tables). In the process of data analysis, particular attention was paid to the existence of emissions in the set of values and to find out their cause [11]. It should be noted that the study of numerical characteristics and the laws of the distribution of values of the indicated indicators is a prerequisite for the correctness of the use of mathematical methods for the subsequent stages of the analysis of experimental data. The main numerical characteristics of soil fertility and protein content in winter wheat are given in Table 2 .

Table 2 - Numerical Characteristics of Soil Fertility Indices and Protein Content in Winter Wheat

\begin{tabular}{|l|l|l|l|l|}
\hline \multirow{2}{*}{\multicolumn{1}{|c|}{ Summary Statistics }} & \multicolumn{4}{|c|}{ Conditional designation of indicators } \\
\cline { 2 - 5 } & \multicolumn{1}{|c|}{$y$} & \multicolumn{1}{c|}{$x_{1}$} & \multicolumn{1}{c|}{$x_{2}$} & \multicolumn{1}{c|}{$x_{3}$} \\
\hline Count & 35 & 35 & 35 & 35 \\
\hline Average & 12,84 & 15,0143 & 102,371 & 242,086 \\
\hline Median & 13,0 & 12,5 & 99,0 & 233,0 \\
\hline Mode & 13,0 & 10,5 & 95,0 & \\
\hline Variance & 3,94776 & 55,6983 & 583,476 & 4890,43 \\
\hline Standard deviation & 1,9869 & 7,46313 & 24,1552 & 69,9316 \\
\hline Coeff. of variation & $15,4743 \%$ & $49,7069 \%$ & $23,5957 \%$ & $28,8871 \%$ \\
\hline Standard error & 0,335847 & 1,2615 & 4,08298 & 11,8206 \\
\hline Minimum & 8,2 & 4,5 & 37,0 & 118,0 \\
\hline Maximum & 17,8 & 42,0 & 170,0 & 436,0 \\
\hline Range & 9,6 & 37,5 & 133,0 & 318,0 \\
\hline Stnd. skewness & 0,168426 & 4,11054 & 0,378812 & 1,81053 \\
\hline Stnd. kurtosis & 0,491172 & 4,6965 & 2,35483 & 1,22187 \\
\hline
\end{tabular}


The comparison of the mean and median, the analysis of the normalized asymmetry and excess coefficients shows that the distribution of the nitrogen nitrogen content index can be considered close to the normal law, for the remaining indices - far from the normal distribution law. Such conclusions are confirmed by both constructed histograms and block diagrams - "boxes with mustache" indicators (Figure 1)

Histogram

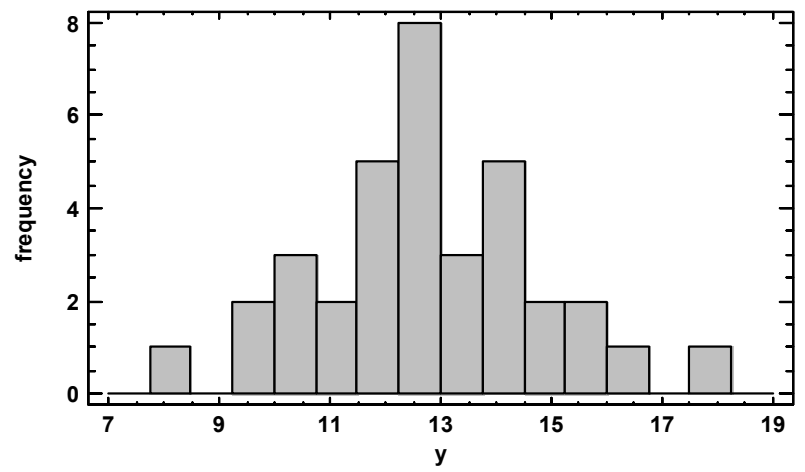

Histogram

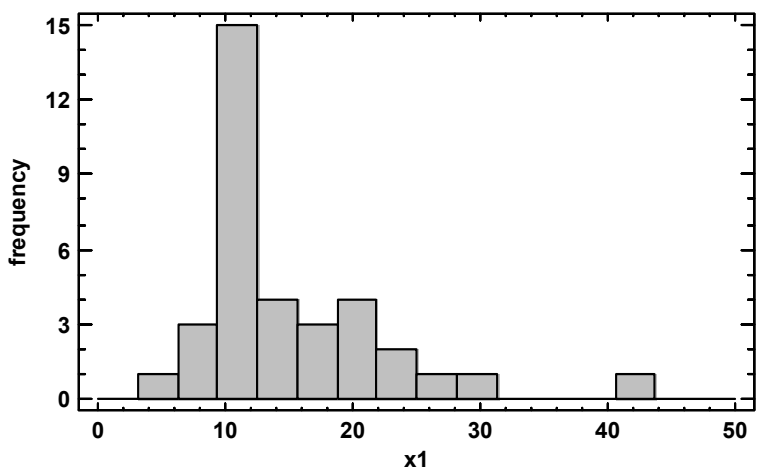

a)

b)

Histogram

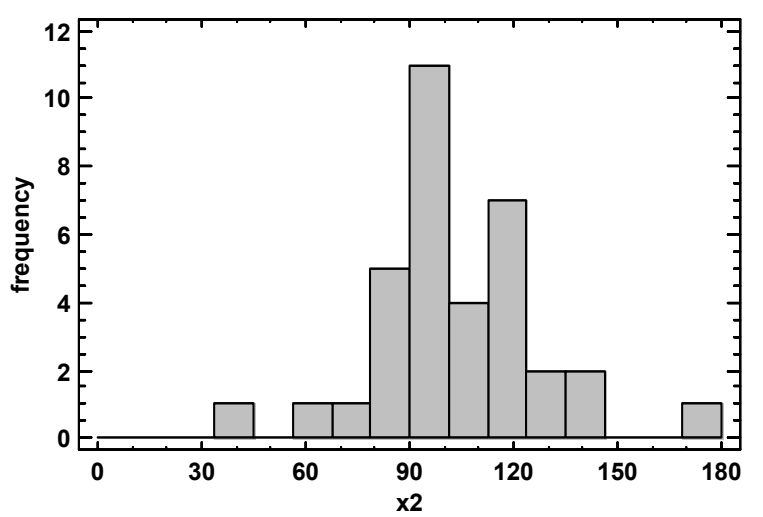

c)

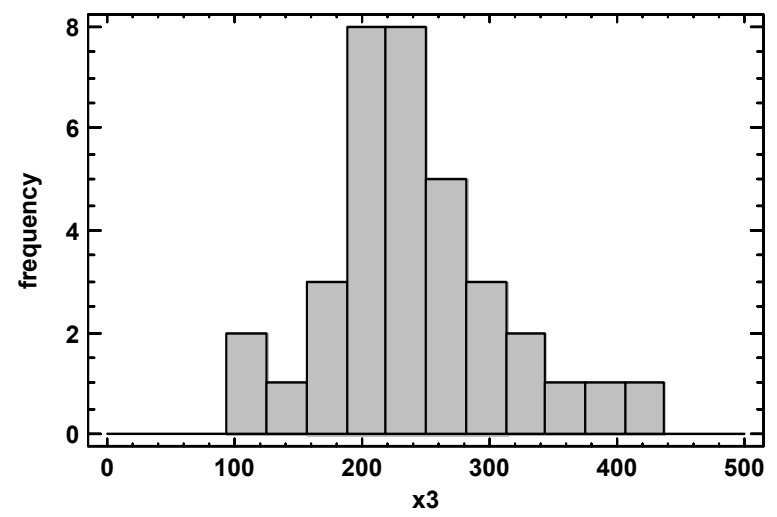

d) 


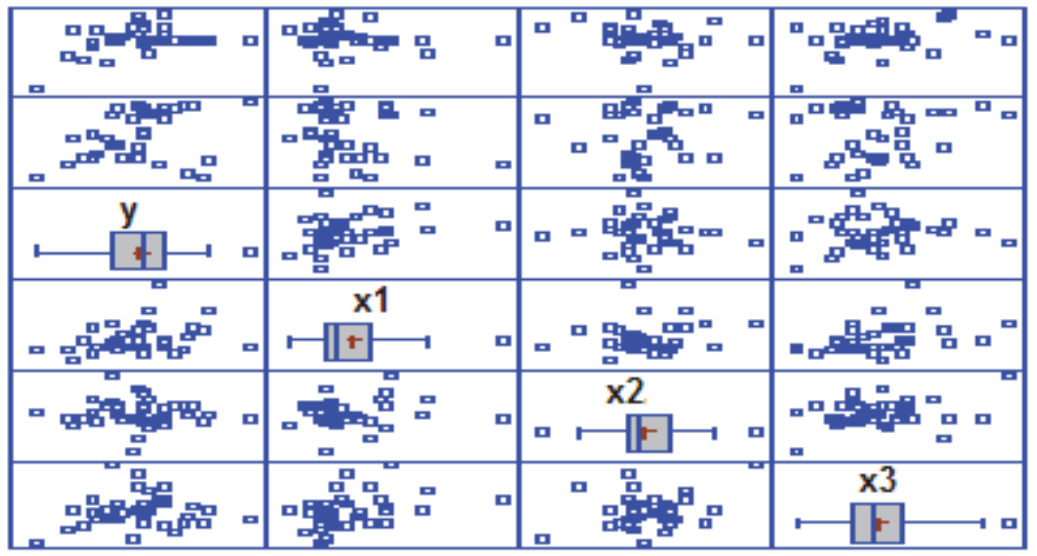

e)

Fig. 1 - Histograms: protein content in wheat grains of winter - a),

nitrogen nitrates $-b$ ), phosphorus $-c$ ), potassium -d), Box-and-Whisker Plot of these indicators e).

At the next stage, coefficients of correlation of protein content in winter wheat grains and soil fertility indices were calculated, namely: $r_{y x_{1}}=0,263, r_{y x_{2}}=-0,0506, r_{y x_{3}}=0,0937$. The content of wheat protein of winter is most closely related to nitrogen nitrogen content, correlation coefficients of phosphorus and potassium are low. By means of regression equations, determination coefficients $(R)$ of pair regression dependences were calculated (Table 3).

Table 3 - Pair Regression Dependences of Protein Content in Grain (y) on Soil Fertility Indicators $\left(x_{1}, x_{2}, x_{3}\right)$

\begin{tabular}{|c|c|}
\hline Indicator of soil fertility & Regression equation \\
\hline Nitrogen content of nitrates $\left(x_{1}\right)$ & $y=\frac{1}{0,07+\frac{0,123}{x_{1}}}, \quad R^{2}=11,794 \%$ \\
\hline The content of phosphorus $\left(x_{2}\right)$ & $y=\sqrt{177,93-0,0008 x_{2}^{2}}, R^{2}=0,693 \%$ \\
\hline Potassium content $\left(x_{3}\right)$ & $y=\frac{1}{0,067+\frac{2,1935}{x_{3}}}, R^{2}=9,363 \%$ \\
\hline
\end{tabular}


The comparative dependence of protein content in winter wheat grain on the change in the nutrient content in the soil, namely, the higher content of nitrogen nitrogen $\left(R^{2}=11,794 \%\right)$ the average from changes in the content of mobile potassium, $\left(R^{2}=9,363 \%\right)$ low-change in the content of mobile phosphorus $\left(R^{2}=0,693 \%\right)$.

To detect changes in the protein content of winter wheat, its predictive values were calculated by the equation: $y_{1}=\frac{1}{0,075+\frac{0,039}{t}}$ [12]. The statistical quality of this model is evidenced by the determination coefficient $\left(R^{2}=28,94 \%\right)$, Fisher's criterion $(F=13,44)$, Darbin-Watson criterion $(D W=1,89)$.The predicted values of protein content in winter wheat grains tend to increase.

Since the content of protein in winter wheat grains is co-effected by three soil fertility indices, it is advisable to determine the level of their joint action using the integral index $\left(I_{j}\right)$.To determine the coherent influence of soil fertility indices on the protein content of winter wheat grain, experimental data were calculated according to the regression equation, which has the form: $y=\sqrt{130,694+124,81 /}$. The value of the integral index varies in the range from 0 to 1 . The calculated values of the integral index of soil fertility level according to the experimental data are shown in Figure 2.

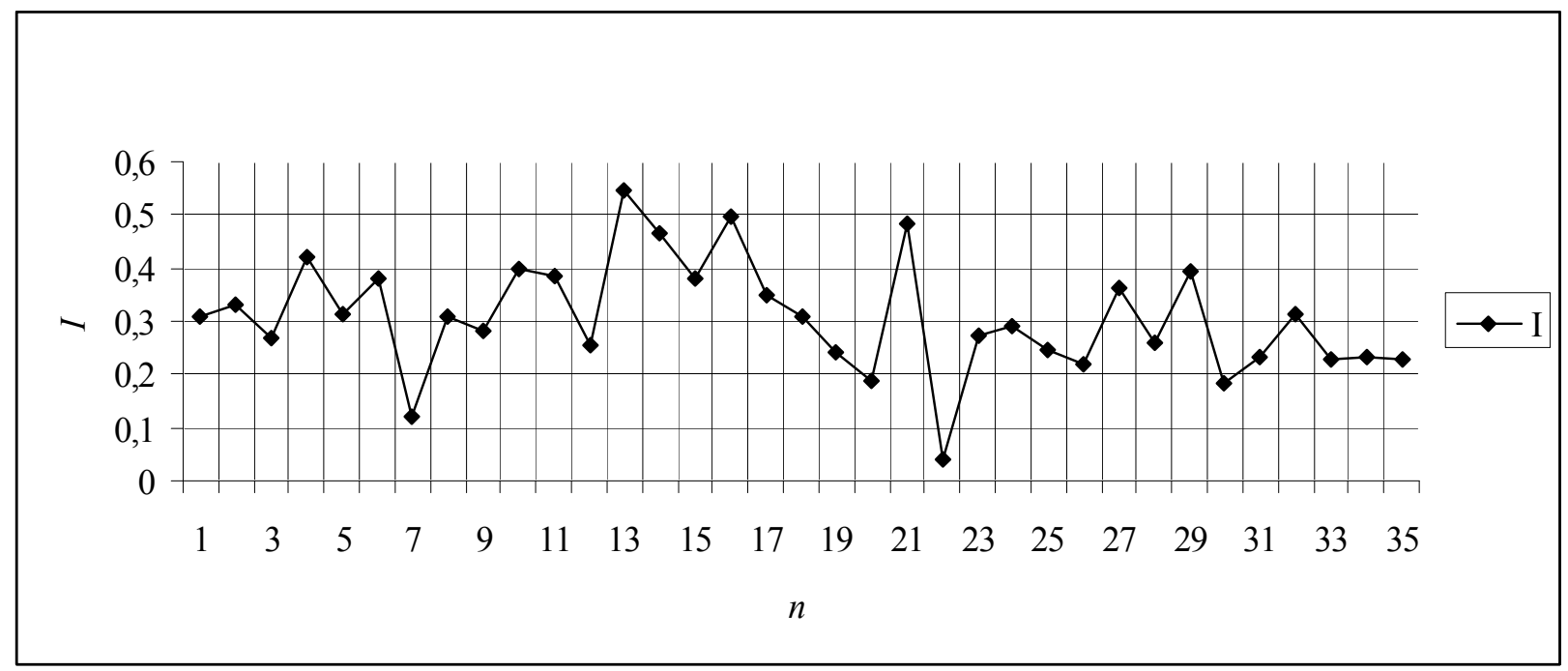

Fig. 2 - Changes in the values of integral index of soil fertility. $(I)$ calculated by the taxonomic coefficient of development [11], where $\mathrm{n}$ is the field experiment number.

The maximum value of the integral index of soil fertility level is equal $I_{\max }=0,5449$, which corresponds to the content of nitrogen nitrogen

$x_{1}=42,0 \mathrm{mg} / \mathrm{kg}$ of soil; content of mobile phosphorus $x_{2}=91$; contents of moving potassium $x_{3}=290 \mathrm{mg} / \mathrm{kg}$ of soil. At the same time the level of protein in grain is $13.7 \%$.

Thus, a methodical approach to the mathematical processing of experimental information of field experiments has been developed, for example, to determine the dependence of soil fertility indices on the protein content of winter wheat grains under the conditions of the steppe zone (Table 4). 
Table 4 - Stages of Mathematical Processing of Experimental Information of Field Experiments

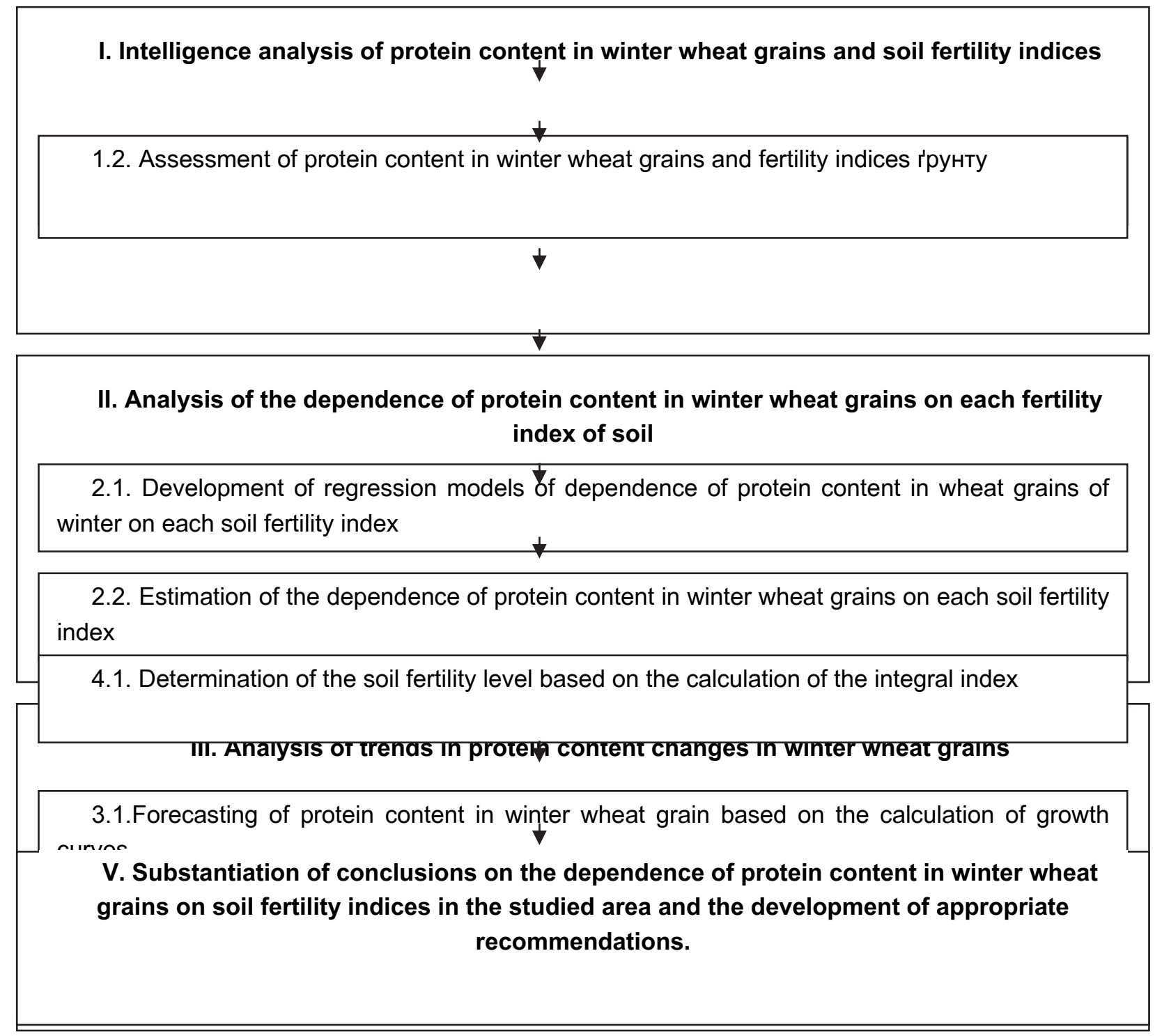

IV. Analysis of the combined effect of soil fertility indices on protein content in winter wheat grains

4.2. Development of regression models of dependence of protein content in winter wheat grains on integral soil fertility index 
Bibliography

1. Schepetyev M.A. (2012). Accumulation of elements of nutrition of winter wheat and influence on crop and quality of grain. Engineering bulletin of Don. T. 23. No. 4. 91 p. [in Russian].

2. Petrichenko V.F., Korniychuk O.V. (2018). Factors of stabilization of winter wheat grain production in the Forest-steppe Right Bank. Bulletin of Agrarian Science. No 2. p. 17-23. [in Ukraine].

3. Ferdoush J.N., Rahman M.M. (2013). Effects of Boron Fertilization and Sowing Date on the Grain Protein Content of Wheat Varieties. J. of Environmental Science and Natural Resources. № 6 (1). P. 41 45.

4. Shejalova S., Cerny J., Mitura K. et al. (2014). The influence of nitrogen fertilization on duality of winter wheat grain. Mendel Net. Crech Republic. V. 1. P. $105-109$.

5. Hlisnikovski L., Kunzova E.(2014). Effect of Mineral and Organic Fertilizers on Yieldand Technological Parameters of Winter Wheat (Triticum aestivum L.) on Illimerized Luvisol. Polish J. of Agronomy. № 17. P. 18 - 24.

6. Nuttall J.G., O'Leary G.J., Panozzo J.F. et al. (2017). Models of grain quality in wheat. Field Crops Research. V. 202, 15 February. P. $1-4$.

7. Boyko G.I. Peculiarities of Harvesting and Grain Quality of Winter Wheat in Connection with the Type of Soil and Fertilizers in the Southern Polesie of the USSR. Agrochemistry. 1976. No. 5. p. 72-77. [in Russian].

8. Lisovy M.V., Komarysta A.V. (2015). Influence of soil fertility indices on the quality of winter wheat grains on soddy podzolic soils of Polissya. Bulletin of Agrarian Science: Theoretical Sciences. journ NAAS of Ukraine. No. 11. p. 10-12. [in Ukraine].

9. Bakayeva N.P., Saltykova O. L. (2011). Productivity and biochemical indices of quality of winter wheat depending on soil fertility in the forest-steppe of the Volga region. Scientific perspective. № 8. p. 69-71. [in Russian].

10. Lisovyi M.V. (2016). Normative indicators of the quality of winter wheat grains on the black earths of the forest-steppe and steppe. The Bulletin of Agrarian Science: Theoretical Sciences. journ NAAS of Ukraine. No. 8. p. 5-7. [in Ukraine].

11. Ponomarenko V.C. Malyarets L.M. (2009). Analysis of data in researches of socio-economic systems: monograph. Kharkiv: "INZHEK" VD. 432 p. [in Ukraine].

12. Malyarets L.M. (2010). Economic-mathematical modeling: a tutorial. Kharkiv: View. XHEY. 312 p. [in Ukraine].

13. Grin G.S., Krupsky M.K. (1969). Principles of Agro-Soil Regionalization of the Ukrainian SSR. Agrochemistry and Soil Science: Republican Interdepartmental Thematic Scientific Collection. Kiev. No. 12. p. 3-26. [in Ukraine]. 